Int. J. Electrochem. Sci., 11 (2016) $6775-6790$

\title{
Electrochemical Analysis of 4-methyl-2-phenyl-imidazole Adsorbed on $\mathrm{Cu}$
}

\author{
Matjaž Finšgar \\ University of Maribor, Faculty of Chemistry and Chemical Engineering, Smetanova ulica 17, 2000 \\ Maribor, Slovenia \\ E-mail: matjaz.finsgar@um.si
}

doi: $10.20964 / 2016.08 .33$

Received: 27 February 2016 / Accepted: 18 March 2016 / Published: 7 July 2016

\begin{abstract}
Herein, for the first time a detailed electrochemical analysis of $\mathrm{Cu}$ immersed in $3 \mathrm{wt} \% \mathrm{NaCl}$ containing 4-methyl-2-phenyl-imidazole (MePhI) as a corrosion inhibitor was performed. This analysis was carried out by means of cyclic voltammetry, chronopotentiometry, and electrochemical impedance spectroscopy (EIS). There was a special focus on EIS measurements. It was shown that MePhI significantly inhibits copper oxidation to $\mathrm{Cu}(\mathrm{I})$ and $\mathrm{Cu}(\mathrm{II})$. The system becomes more noble when $\mathrm{Cu}$ is immersed in MePhI-containing solution compared to non-inhibited solution. EIS measurements revealed that $\mathrm{Cu}$ in inhibited solution undergoes mixed kinetic-controlled and diffusion-controlled processes. A high corrosion inhibition effect was also proven after 180 days of immersion. Moreover, contact angle analysis showed that $\mathrm{MePhI}$ increases the hydrophobic character of the $\mathrm{Cu}$ surface.
\end{abstract}

Keywords: Copper, Corrosion Inhibitor, 4-methyl-2-phenyl-imidazole, Cyclic Voltammetry, Electrochemical Impedance Spectroscopy

\section{$\underline{\text { FULLTEXT }}$}

(C) 2016 The Authors. Published by ESG (www.electrochemsci.org). This article is an open access article distributed under the terms and conditions of the Creative Commons Attribution license (http://creativecommons.org/licenses/by/4.0/). 